\title{
EQUiLIBRIUM
}

Quarterly Journal of Economics and Economic Policy

2015 VOLUME 10 ISSUE 4, December

p-ISSN 1689-765X, e-ISSN 2353-3293

www.economic-policy.pl

Turečková, K. (2015). Income Inequality by Method of Non-weighted Average Absolute Deviation: case study of Central and Eastern European Countries. Equilibrium. Quarterly Journal of Economics and Economic Policy, 10(4), pp. 99-110, DOI: http://dx.doi.org/10.12775/ EQUIL.2015.037

Kamila Turečková*

Silesian University in Opava

School of Business Administration in Karviná, Czech Republic

\section{Income Inequality by Method of Non-weighted Average Absolute Deviation: Case Study of Central and Eastern European Countries**}

JEL Classification: $C 13 ; D 31 ; 132$

Keywords: income inequality; index; comparison; method of non-weighted average absolute deviation

\begin{abstract}
The presented article uses the method of non-weighted average absolute deviation for expressing income inequality in 11 selected Central and Eastern European Countries. Specifically, the analysis of income inequality is done for Poland, the Czech Republic, the Slovak Republic, Austria, Slovenia, Hungary, Romania, Bulgaria, Latvia, Lithuania and Estonia. Based on the determination of income inequality in the article an analysis is made concerning the development of income inequality, including the subsequent inter-regional comparison in the context of the degree of income inequality in a given human society and economy. The text of this article is organized in 4 parts, after Introduction follows the analytic chapter where, primarily, the method of non-weighted average absolute deviation is explained. The third part contains the empirical analysis of income inequality, and the Conclusion highlights some major conclusions
\end{abstract} Toruń

(C) Copyright Institute of Economic Research \& Polish Economic Society Branch in

Date of submission: February 14, 2015; date of acceptance: August 23, 2015

* Contact: tureckova@opf.slu.cz, School of Business Administration in Karviná, Univerzitní náměstí 1934/3, Karviná, Czech Republic

** This paper was supported by the project SGS/13/2015 "Influence of Selected Macroeconomic and Microeconomic Determinants on the Competitiveness of Regions and Firms in Countries of the Visegrad Group Plus". 
of detailed analysis made in Chapter 3. The analysis of income distribution of 11 European households between years 2005-2013 and its order is made in deciles basing on empirical data from the Statistics on Living Conditions and Welfare published by Eurostat.

\section{Introduction}

Income inequality was and also is a natural part of every economy and its society. Income inequality, in essence, means that different people or different groups of people will reach different income, and this income dispersion determines how much the great range of individual income in society at the economy is (Turečková \& Kotlánová, 2014a, pp. 240-247). The phenomenon of poverty and inequality accompanies human society, almost from the very beginning of its existence (Lapáček, 2007). According to Samuelson and Nordhaus (2010), the invisible hand of the market is very effective at allocation of resources and production of goods and services, but can produce simultaneously very unequal distribution of income. Stiglitz (2007) also admits that there is a substitution relationship between efficiency and equality, and therefore to achieve equality it is usually required to give up parts of effectiveness. There are many possibilities how to look at or measure the standards of living in selected countries. One of the best known is GDP per capita. Despite the fact that this indicator could reach a relatively large value, it does not predicate differences of incomes in society. Another indicator we could hear about very often is the average wage. Not even its amount is a guarantee of economic well-being. It is usual that over $50 \%$ of working population of the country cannot reach this amount. One of the best known and used measures of income inequality is Gini coefficient and its graphical representation through Lorenz curve. It could be supplemented by Robin Hood Index and S80/S20 Ratio, which are used as other methods of comparison of income inequality (Turečková \& Kotlánová, 2014b, pp. 1063-1057).

The ability to measure and define income inequality is essential for the subsequent analysis of the determinants of income inequality which is given to the context. For example, imperfect financial institutions cause income inequality, as well as inefficient capital allocation (Daisaka et al., 2014 , p. 4) or technological changes are often identified as one of the driving forces behind recent rises in inequality (Lemieux, 2008, pp. 21-48). This can be given in the context of Rosen (1981, pp. 757-775), who takes the view that one reason for the impact of technological changes on income distribution is the well-known "economics of superstars", because technologies enable top talents to capture increasingly large share of the market. 
For more information about relationship between income inequality and the knowledge economy (see Peng 2014).

Income inequality also resides on spatial dimension, where an increase in regional integration associated with the amelioration of inequality at one level usually corresponds to a reproduction of inequality at higher geographical levels (Novotný, 2007, p. 575). For example, you can also see: Paredes et al. (2012, pp. 1 - 33). Williamson (1965, pp. 3-47) proposes that unequal initial endowments imply a spatial income disparity, but market mechanisms, mainly through labor and firm mobility, lead to the decline of nay regional disparity in the long run. Also interesting is the impact of income inequality between households on the housing market. This is partly due to the spatial dimensions, which according to Dewilde and Lancee (2013) there is a positive relation between inequality and crowding and also higher income inequality is associated with lower housing quality.

This article is characterized by introducing and using an alternative method for measuring, expressing and analysing income inequality in case of Central and Eastern European inhabitants in the period of 2005-2013. Among well-known methods of measuring income inequality there are, traditionally, Lorenz curve, Gini coefficient, Coefficient of income inequality S80/S20 (or Quintile share ration or S80/S20 Ratio), Atkinson index, Theil index, Robin Hood index and Variation coefficient. For more information about these methods see, for example, Atkinson (1970, pp. 244263), Dalton (1920), Lapáček (2007), Litchfield (1999), Schutz (1951, pp. 107-122) or Wolff (2009). Analysis of income inequality is focused on method of non-weighted average absolute deviation that is not normally used in context of income inequality. The great advantage of using this method is its mathematical-algebraic procedure for calculating the coefficient expressing the degree of inequality directly adapted to the data format in which the data concerning income distribution are provided by statistical organizations. Previous research proved an extremely positive and high correlation between the results and evaluation of income inequality by the method here used, and the standard methods, such as the Gini coefficient, index S80/S20 or Robin Hood index (Turečková, 2015b, 2015b). The analysis of income inequality through the abovementioned method will be based on empirical data of Eurostat in the chosen period of time for 11 selected European countries, namely for Poland, the Czech Republic, the Slovak Republic, Austria, Slovenia, Hungary, Romania, Bulgaria, Latvia, Lithuania and Estonia. 


\section{2}

The rest of the article is structured as follows: the next section provides same theoretical introductions and proposals of method of non-weighted average absolute deviation and its decomposition. It also discusses the advantages and disadvantages of using this method in the context of measures of income inequality. Section 3 contains the analysis of the income inequality in selected European countries using the method of non-weighted average absolute deviation. The development of income inequality during analyzed period of time with evaluation of countries and their ranking is also mentioned. Finally, the Conclusion contains some general comments.

\section{Method of the Research}

The method of average deviation reflects the degree of variability, defined as the arithmetic average of the absolute deviations of individual values of observed indicators from the selected value (given point) (for more information about method of absolute average deviation see, for example, Tuleja (2009) or Babu \& Rao (1990). This method can be also named as Method of mean absolute deviation. Generally, the deviation is reckoned from the ideal value, the recommended value, the central value that is constructed as some type of average, median, mean of the data set and other. This value chosen here understands the value for the ideal distribution of income in society, i.e. the value of expressing absolute equality in the income for each inhabitant. In general, absolute deviation is constructed on the basis of this formula 1:

$$
d_{i}=\left|x_{i}-(x)\right|
$$

where:

$\mathrm{d}_{\mathrm{i}}$ presents the absolute deviation from i-th indicator, $x_{i}$ presents the $i-t h$ indicator (data element, variable),

$(\mathrm{x})$ is the chosen given point.

Indicator $(x)$ is the ideal percentage value of income which get in concrete the percentage of households in society, for example, $10 \%$ of households get precisely $10 \%$ of total income $((x)=10 \%)$. Variable $\mathrm{x}_{\mathrm{i}}$ presents real household's money income cumulated into relevant deciles, quintiles, quartile and other. Here, we can give an example that $30 \%$ of households got $16.7 \%$ of total income in Czech Republic in $2010\left(\mathrm{x}_{\mathrm{i}}=\right.$ $16.7 \%)$. The own value of non-weighted average absolute deviation was obtained from the formula 2 : 


$$
\overline{\mathrm{d}}_{\mathrm{i}}=\frac{\sum_{i=1}^{p}\left|x_{i}-(\bar{x})\right|}{\mathrm{n}_{\mathrm{i}}}
$$

where:

$\overline{\mathrm{d}}_{\mathrm{i}}$ presents the average absolute deviation from i-th indicator, $\mathrm{n}_{\mathrm{i}}$ presents the number of values of $\mathrm{i}$-th indicator that we have available, $(\bar{x})$ is the arithmetic mean of $\mathrm{i}$-th indicator.

A particular form for using this method is to set the time integrated value of the index (3) for relevant evaluation of selected indicators during analysed period of time. Based on this calculated index we can determine the intertemporal ranking of the chosen regions or countries or identify differences between them. We compile the value of intertemporal integrated index by following formula:

$$
\mathrm{INI}_{\mathrm{P}}=\frac{\sum_{i=1}^{p}\left|\overline{\mathrm{d}}_{\mathrm{i}}\right|}{\mathrm{n}_{\mathrm{i}}} \quad \text { or } \quad \mathrm{D}_{\mathrm{ii}}=\frac{\sum_{i=1}^{p}\left|\overline{\mathrm{d}}_{\mathrm{i}}\right|}{\mathrm{n}_{\mathrm{i}}}
$$

where:

$\mathrm{INI}_{\mathrm{P}}$ is an integrated index calculated using the average absolute deviation, where $\mathrm{INI}_{\mathrm{P}} \in\langle 0,100\rangle$,

$\mathrm{D}_{\mathrm{ii}}$ integral index for income inequality (special label).

Integrated index $\left(\mathrm{INI}_{\mathrm{P}}\right)$ express the average value of variable $\overline{\mathrm{d}}_{\mathrm{i}}$ during the analysed period of time. Integrated index in context of measuring income inequality will be marked as $\mathrm{D}_{\mathrm{ii}}$ (deviation of income inequality). Both value of non-weighted average absolute deviation and amount of integrate index can have values from 0 to 100 , and if the value of non-weighted average absolute deviation and amount of integrate index is lower (the more close to 0 ) than there is less income inequality between the richest and poorest households in society. Perfect income equality in the society would occur in a situation where both values would come out zero.

The intertemporal integrated index based on methods of non-weighted average absolute deviation is useful for simple comparison of income inequality in large number of societies (communities) together during a long period of time. It is also much easier to use and apply the method of nonweighted average absolute deviation to express income inequality than count Gini coefficient, because the results of both methods are essentially identical, more in Turečková a Kotlánová (2015, pp. 835-840) or Turečková (2015, pp. 438-446). As it was mentioned in Introduction, two other 
studies were conducted. The results of the level of income inequality measured through 3 methods were compared, using new methods of nonweighted average absolute deviation and two standard methods: Gini coefficient and S80/S20 Ratio. The correlation between them was very high, which means that there is a high significant dependence between selected variables. Since the correlation between the results obtained with the method of non-weighted average absolute deviation and Gini coefficient is significant, it is advisable to use the method of non-weight average absolute deviation to express the deviation in income inequality instead of Gini coefficient, whose calculation is considerably more difficult. The negative of using the intertemporal integrated index is that the value of this index does not tell us anything about the development (or the trend) of income inequality in the society during the time.

From a methodological perspective, the work is based on secondary data gained by Eurostat, concretely from the Population and social conditions, Living conditions and welfare, Income distribution and monetary poverty, Distribution of income by deciles as a share of national equivalised income for 11 European countries: Poland, the Czech Republic, the Slovak Republic (Slovakia), Austria, Slovenia, Hungary, Romania, Bulgaria, Latvia, Lithuania and Estonia. The covered period includes years 2005-2013 because of missing credible data, which is not available for a longer period.

Income is understood as a total disposable income of a household that is calculated by counting personal income received by all members of the household, plus the income received at household level. Disposable household income includes all income from work (employee wages and selfemployment earnings), private income from investment and property, transfers between households and all social transfers received in cash including old-age pensions (Eurostat, 2015).

Calculations of value of non-weighted average absolute deviation and integrated index $\left(\mathrm{D}_{\mathrm{ii}}\right)$ are based on calculations using formulas (1), (2) and (3). All these measures of income inequality were described in the text above. The software used was MS Excel. All calculations and graphical analysis is Author's own.

\section{Empirical Analysis and Findings}

Empirical analyses were made on the basis of the share of national equivalised income of 11 Central and Eastern European countries household's data from Eurostat (2015). Subsequently, on the basis of the data, through method of non-weighted average absolute deviation, we compute 
the values that by the set way characterize income inequality. We can also compare these values to determine the income inequality between countries or characterize development of income inequality in relevant country over the period of time.

Figure 1 is showing the development of values of average absolute deviation for selected eleven European countries for the years 2005-2013. It shows that the country which has the best income equality from analysed group of countries is Slovenia. Through the graphical interpretation of income inequality shown in Figure 1, one can clearly see the natural division of the countries analysed in two groups. Group of countries with higher income equality forms already mentioned Slovenia, followed by Slovakia, Austria, Czech Republic and Hungary, whose development in income inequality has a considerable dynamics, which is not desirable. The group of countries with higher income inequality, whose values of income inequality calculated by non-weighted average absolute deviation are higher than the first group, consists of all three Baltic States, Poland, Romania and Bulgaria.

Figure 1. Development of values of income inequality calculated by non-weighted average absolute deviation $\left(\overline{\mathrm{d}}_{\mathrm{i}}\right)$ in selected European countries (11), (2005-2013)

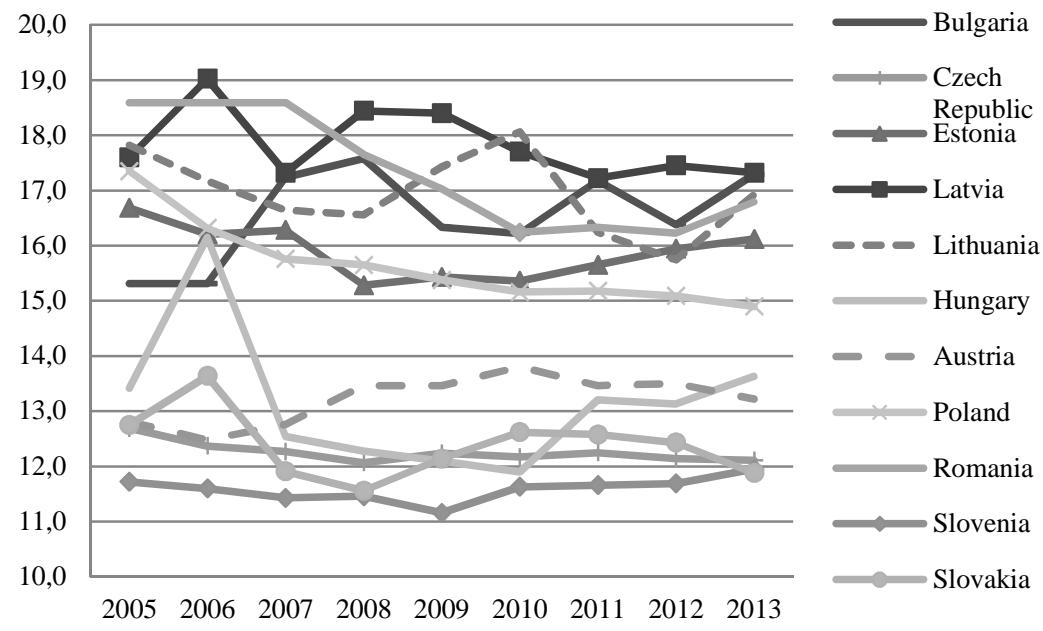

Source: own calculations based on Eurostat (2015). 
Figure 1 shows that only Poland achieved continuous decline in income inequality (by 2.5 point) during the period. As we can see also from this graph, there were not any significant changes in income inequality/income equality in other 9 selected countries (except Bulgaria, where its increased value indicating income inequality by 2 points) in the set period of time.

Table 1 complements Figure 1 and presents a value of income inequality calculated by non-weighted average absolute deviation in analyzed European countries for years 2005-2013. Table 1 is supplemented with a multicolored range where the darker the tint value in the cell is given by the country for that year characterized by higher income inequality. Countries with a light tint are doing in the context of income equality better than those for which it is darker tint values.

Table 1. Values of income inequality calculated by non-weighted average absolute deviation $\left(\overline{\mathrm{d}}_{\mathrm{i}}\right)$ in selected European countries (11) for each year supplemented with a multicolored range

\begin{tabular}{|l|c|c|c|c|c|c|c|c|c|}
\hline Geo/Year & $\mathbf{2 0 0 5}$ & $\mathbf{2 0 0 6}$ & $\mathbf{2 0 0 7}$ & $\mathbf{2 0 0 8}$ & $\mathbf{2 0 0 9}$ & $\mathbf{2 0 1 0}$ & $\mathbf{2 0 1 1}$ & $\mathbf{2 0 1 2}$ & $\mathbf{2 0 1 3}$ \\
\hline Bulgaria & 15.3 & 15.3 & 17.2 & 17.6 & 16.3 & 16.2 & 17.2 & 16.4 & 17.3 \\
\hline Czech Republic & 12.7 & 12.4 & 12.3 & 12.1 & 12.2 & 12.2 & 12.3 & 12.1 & 12.1 \\
\hline Estonia & 16.7 & 16.2 & 16.3 & 15.3 & 15.4 & 15.4 & 15.7 & 15.9 & 16.1 \\
\hline Latvia & 17.6 & 19.0 & 17.3 & 18.4 & 18.4 & 17.7 & 17.2 & 17.5 & 17.3 \\
\hline Lithuania & 17.8 & 17.2 & 16.6 & 16.6 & 17.4 & 18.1 & 16.2 & 15.7 & 16.9 \\
\hline Hungary & 13.4 & 16.2 & 12.5 & 12.3 & 12.1 & 11.9 & 13.2 & 13.1 & 13.6 \\
\hline Austria & 12.8 & 12.5 & 12.8 & 13.5 & 13.5 & 13.8 & 13.5 & 13.5 & 13.2 \\
\hline Poland & 17.4 & 16.3 & 15.8 & 15.7 & 15.4 & 15.2 & 15.2 & 15.1 & 14.9 \\
\hline Romania & 18.6 & 18.6 & 18.6 & 17.7 & 17.0 & 16.2 & 16.3 & 16.2 & 16.8 \\
\hline Slovenia & 11.7 & 11.6 & 11.4 & 11.5 & 11.2 & 11.6 & 11.7 & 11.7 & 12.0 \\
\hline Slovakia & 12.8 & 13.6 & 11.9 & 11.6 & 12.1 & 12.6 & 12.6 & 12.4 & 11.9 \\
\hline Mean & 15.2 & 15.4 & 14.8 & 14.7 & 14.6 & 14.6 & 14.6 & 14.5 & 14.7 \\
\hline
\end{tabular}

Source: own calculations based on Eurostat (2015).

There is also data about a mean value for each year. Comparing these values, we find that in the course of 9 years, income inequality across groups of countries as a whole declined (from 15.2 point to 14.7 point). If you simply compare values between year 2005 and year 2013 then there is an improvement in income equality in the Czech Republic, Esto- 
nia, Latvia, Lithuania, Poland, Romania and the Slovak Republic. Deepening income inequality occurred in Bulgaria, Hungary, Austria and Slovenia.

The value of (intertemporal) integrated index $\mathrm{D}_{\mathrm{ii}}$ representating the level of income inequality in society in each country is shown in Table 2. This index averages the values obtained by the non-weighted average absolute deviation for the whole analysing time series. Basing on the amount of this index, we can compile the ranking of countries based on their uniform distribution of income in the society.

Table 2. Amount of intertemporal - integral index for income inequality and the ranking of countries in context of income inequality for selected European countries (11), lined up

\begin{tabular}{|l|c|c|c|c|c|}
\hline $\begin{array}{l}\text { Index/ } \\
\text { Geo }\end{array}$ & Slovenia & Czech Republic & Slovakia & Hungary & Austria \\
\hline $\mathrm{D}_{\mathrm{ii}}$ & 11.59 & 12.26 & 12.39 & 13.15 & 13.22 \\
\hline Ranking & 1 & 2 & 3 & 4 & 5 \\
\hline
\end{tabular}

\begin{tabular}{|l|c|c|c|c|c|c|}
\hline $\begin{array}{c}\text { Index/ } \\
\text { Geo }\end{array}$ & Poland & Estonia & Bulgaria & Lithuania & Romania & Latvia \\
\hline $\mathrm{D}_{\mathrm{ii}}$ & 15.64 & 15.88 & 16.54 & 16.95 & 17.34 & 17.83 \\
\hline Ranking & 6 & 7 & 8 & 9 & 10 & 11 \\
\hline
\end{tabular}

Source: own calculations based on Eurostat (2015).

Graphs of the results (see Figure 2) of the index $D_{\text {ii }}$ are more easily legible and complete Table 2. The income inequality was the lowest in Slovenia during the years 2005-2013, where the intertemporal integrated index was 11.59. About 0.67 points after Slovenia, in second place with the lowest income inequality, was the Czech Republic, and about 0.8 points, in third place was Slovakia (the Slovak Republic) within the selected group of countries followed by other analysed European countries. The average value of the index, the mean, is 14.8 points. The worst situation in context of income inequality was in Latvia, where the amount of integrated index was 17.83 points for time period 2005-2013. 
Figure 2. Development of values of income inequality calculated by non-weighted average absolute deviation $\left(\overline{\mathrm{d}}_{\mathrm{i}}\right)$ in selected European countries (11), (2005-2013)

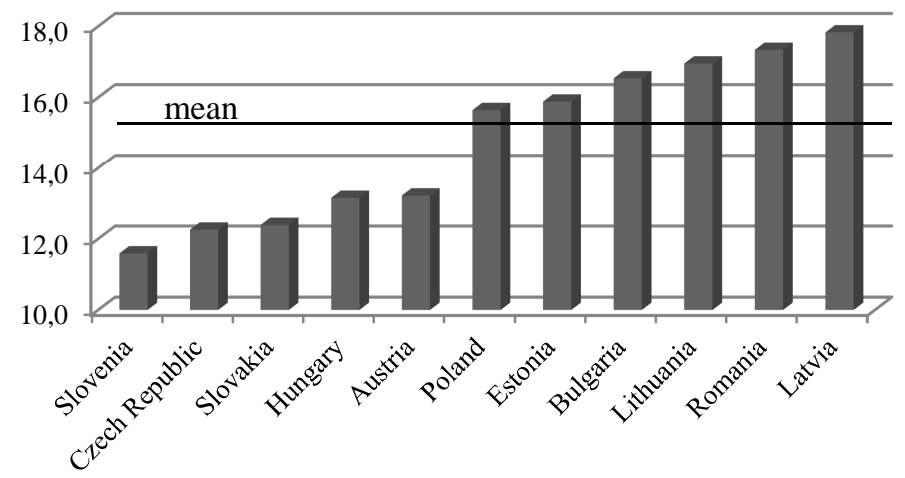

Source: own calculations based on Eurostat (2015).

Figure 2 shows another interesting fact. From the geographic point of view, countries with higher income equality concentrated in the central European region, while the countries with higher income inequality make up the group Baltic countries, along with Poland, Romania and Bulgaria, it means the Eastern European countries acceding to the European Union at the end of the integration process and countries in transition problematic process. For further research, the question is whether that income inequality is not related to the geographic location, which in turn determines the other factors involved in the distribution of income in society.

\section{Conclusions}

There are a lot of methods, procedures and approaches to measurement and describing income inequality in our economy and our society. In this paper is paid attention to new (alternative) method of measuring and expressing income inequality through method of non-weighted average absolute deviation. It was used to map changes in income inequality of eleven Central and Eastern European countries, namely of Poland, the Czech Republic, the Slovak Republic (Slovakia), Austria, Slovenia, Hungary, Romania, Bulgaria, Latvia, Lithuania and Estonia between years 2005-2013. The ranking of these countries was also assembled in the context of a more equal distribution of income in a given society. It was done on the basis of intertemporal 
integrated index. The highest income equality in the analyzed group of countries was reached by Slovenia; the worst income inequality was in Latvia.

The second conclusion presented in this paper is that non-weighted average absolute deviation method can expand the existing portfolio of methods for measuring and expressing income inequality between households in society because of its comparatively simple feasibility while the results are comparable to standard and traditional methods of measuring income inequality.

\section{References}

Atkinson, A. B. (1970). On the Measurement of Inequality. Journal of Economic Theory, 2.

Babu, G. J., \& Rao, C. R. (1992). Expansions for statistics involving the mean absolute deviations. Annals of the institute of statistical mathematics, 44(2). http://dx.doi.org/10.1007/BF00058648.

Daisaka, H., Furusawa, T. \& Ynagawa, N. (2014). Globalization, financial development and income inequality. Pacific economic review, 19(5). DOI: http://dx.doi.org/10.1111/1468-0106.12086.

Dalton, H. (1920). The measurement of the inequality of incomes. Retrieved from http://www.ophi.org.uk/wp-content/uploads/Dalton-1920.pdf (28.01.2015).

Dewilde, C., \& Lancee, B. (2013). Income inequality and access to housing in Europe. European sociological review, 29(6). DOI: http://dx.doi.org/10. 1093/esr/ jct009.

EUROSTAT. (2015). Category: Living condition glossary. Retrieved from http://epp.eurostat.ec.europa.eu/statistics_explained/index.php/Category: Living_conditions_glossar (28.01.2015).

EUROSTAT. (2015). Statistics: Income distribution and monetary poverty. Retrieved from http://ec.europa.eu/eurostat/data/database (29.01.2015).

Lapáček, M. (2007). Př́jmová nerovnost a ekvivalenční stupnice. Retrieved from http://nf.vse.cz/download/veda/workshops/inequality.pdf (29.01.2015).

Lemieux, T. (2008). The changing nature of wage inequality. Journal of Population Economic, 21(1). DOI: 10.1007/s00148-007-0169-0.

Litchfield, J. A. (1999). Inequality: Methods and Tools. Text for World Bank's Web Site on Inequality, Poverty, and Socio-economic Performance. Retrieved from http://www.worldbank.org/poverty/inequal/index.htm (23.01.2015).

Novotny, J. (2007). On the measurement of regional inequality: does spatial dimension of income inequality matter?. Annals of regional science, 41(3). DOI: http://dx.doi.org/10.1007/s00168-007-0113-y. 


\section{0}

Paredes, D., Iturra, V. \& Lufin, M. (2012). A further step to understand income inequality in Chile: A decomposition using three-stages nested Theil index decomposition method. Retrieved from http://www.researchgate.net/publi cation/235256577_A_further_step_to_understand_income_inequality_in_Chile_A _decomposition_using_three-stages_nested_Theil_index_decomposition_ method (10.02.2015).

Peng, B. C. (2014). Status and income inequality in a knowledge economy. Journal of economic inequality, 12(4). DOI: http://dx.doi.org/10.1007/s10888-0149274-y.

Rosen, S. (1981). The economics of superstars. American Economic Review, $71(5)$.

Samuelson, P. A. \& Nordhaus W. D. (2010). Economics. New York: McGrawHill.

Schutz, R. (1951). On the Measurement of Income Inequality. American Economic Review, 41(1).

Stiglitz, J. E. (1997). Ekonomie veřejného sektoru. Praha: Grada.

Tuleja, P. (2009). Možnosti měření regionálních disparit - nový pohled. Retrieved from http://disparity.idealnihosting.cz/regdis_2008/pdf/13\%20regdis_2008.pdf (05.02.2015).

Turečková, K. \& Kotlánová E. (2014a). Income inequality in the Czech Republic and Slovak Republic. In Proceedings of the International Workshop Ten years of Membership of the Czech and Slovak Republic in the European Union. Karviná: OPF SU Karviná.

Turečková, K. \& Kotlánová E. (2014b). Poverty Analysis and Measuring Income Inequality in Czech Republic. In Mathematical methods in Economics MME 2014 - Conference Proceeding. Olomouc: Faculty of Science, Palacký University.

Turečková, K. \& Kotlánová E. (2015). Method of Non-weighted Average Absolute Deviation in Context of Measuring Income Inequality by Gini Coefficient: case study of Visegrad group countries. In Conference Proceedings: 33rd International Conference Mathematical Methods 2015. Plzeň: University of West Bohemia.

Turečková, K. (2015). Measurement of income inequality by method of nonweighted average absolute deviation: Case of South European Countries. In Proceedings of the 12th International Conference Liberec Economic Forum 2015. Liberec: TU Liberec.

Willianson, J. (1965). Regional inequality and the process of national development. Economic Development and Cultural change 4.

Wolff, E. N. (2009). Poverty and income distribution. 2nd Ed. Chichester, UK: Wiley-Blackwell. 